Vol. 2, No. 2, Juli 2018, 162-174

Available Online at https://ejournal.warmadewa.ac.id/index.php/kulturistik DOI: dx.doi.org/10.22225/kulturistik.2.2.753

\title{
FORMS AND MEANINGS OF ADJUNCTS IN JAMES' FIFTY SHADES OF FREED
}

\author{
I Gede Pande Bayu Pratama \\ Warmadewa University \\ pande_bayu95@yahoo.es \\ Ni Made Susini \\ Warmadewa University \\ madesusini@yahoo.com \\ Anak Agung Gede Suarjaya
Warmadewa University
mynsuar@gmail.com
}

\begin{abstract}
This study is specifically aimed at identifying the forms of adjuncts and the meanings they carry. In order to analyze the data, descriptive-qualitative approach was applied in this research. The data are sentences which contain adverbials functioning as adjuncts and they were taken from a novel entitled Fifty Shades of Freed, written by Erika Leonard Mitchell, also known as E.L. James (2012). They were collected through library research and then presented informally by providing some examples and elaborations. There are some important points that can be concluded based on the results of analysis. First, adjuncts may appear in many forms, either phrases or clauses. Phrases forming adjuncts found in this novel are noun phrases, adverb phrases, and prepositional phrases. Meanwhile, clauses forming adjuncts which appear in this novel are finite verb clauses, non-finite verb clauses (including to-infinitive, bare infinitive, -ing participles, and -ed participles), and verbless clauses. Secondly, there are various meanings carried by adjuncts found in Fifty Shades of Freed. Adjuncts which denote space or place carry the meanings of position, direction, and distance. Adjuncts referring to time carry the meanings of time position, duration, frequency, and time relationship. Adjuncts showing process carry the meanings of manner, means, instrument, and agentive. Besides, there are also adjuncts which imply respect, cause, purpose, and concession found in this novel.
\end{abstract}

Keywords: adjunct, adverbial, form, meaning

\section{INTRODUCTION}

Sentence is a device which is used by people to utter their thought. In order to transfer messages from one person to the others, a sentence must be conveyed either verbally or in writing. A sentence is built from a group of words and of course it must have complete meaning. There are several units those are needed to construct a sentence; they are subject, verb, object, complement, and adverbial. Among the five units, adverbial seems to be the most unique.

Adverbial is commonly realized by adverb with the suffix $-l y$ to describe the action which is represented by the verb of the sentence. Therefore, such adverbial is widely known as adverbial of manner. Other than indicating manner, adverbials can also indicate where an action takes place or when the action hap- 
Vol. 2, No. 2, Juli 2018, 163

Available Online at https://ejournal.warmadewa.ac.id/index.php/kulturistik DOI: dx.doi.org/10.22225/kulturistik.2.2.753

pens. In several cases, the presence of adverbials is optional. It means that even if they are omitted, the meaning carried by a sentence remains complete and grammatically correct. On the other hand, some adverbials are called obligatory if their existence in a sentence is a must. In other words, the meaning conveyed by a sentence will be incomplete when such adverbials are removed.

There is a very closely-related term called adjunct which is commonly used when we talk about adverbials. Adjunct is one type of adverbials which is integrated within the sentence structure, and thus, it also possesses the characteristics of adverbials. In a sentence, adjuncts can be either optional or obligatory. An adjunct can be a single word, a phrase, or an entire clause (Spasić, Babić-Antić, \& Spasić-Stojković, 2015). However, most adjuncts are realized by adverb and prepositional phrases and this makes them difficult to be distinguished from the other types of adverbials. Not only are adjuncts built by those mentioned phrases, but also by noun phrases, adverb phrases, and even clauses. The realization of adjunct itself must be the same as adverbials. Therefore, if the functions of the adverbial are realized by adverb phrases, noun phrases, prepositional phrases, finite verb clauses, non-finite verb clauses, and verbless clauses, then adjuncts can also be constructed by those phrases and clauses (Torikai, 2013). If noun phrase is a phrase with noun as its head, then adverb phrase will have an adverb as the head. Adverb phrase normally modifies the verb of the sentence by providing additional explanation about it. Prepositional phrase, on the other hand, consists of a preposition followed by a noun phrase. Adjuncts which are constructed by finite verb clauses take subordinating conjunctions (after, before, until, since, once, because) as complementiser. The main verb in a finite verb clause carries tense, while in a non-finite verb clause there is no tense. Furthermore, non-finite verb clause is distinguished into to-infinitive, bare infinitive, -ing participle, and $e d$ participle. The infinitive form is quite common. To-infinitive, in accordance with its name, is preceded by particle to. Since there is no tense applied, the verb has the basic stem form. Meanwhile, bare infinitive seems to be simpler. Both toinfinitive and bare infinitive come with basic verb form, but bare infinitive is not followed by particle to. In common with to-infinitive, -ing participle can be complex. They have the same structure except that, instead of the first verb being preceded by to, it takes the -ing affix. On the other hand, -ed participle clause is both syntactically and semantically passive. In other words, even though it is called -ed participle, it is not always that the verbs in this clause have -ed suffix. The verb which plays role here is verb in past participle. Since non-finite verb clauses do not carry tense, they can only fill the position of subordinate clause. Finally, in verbless clause, the ellipsis of the verb be can usually be inferred. Additionally, when the subject is omitted, it can be treated as recoverable from the context. It can also be treated as reduction of non-finite clauses (Petrlíková, 2013).

Syntactically, adjuncts may appear in initial, medial, or even final position of a sentence. Meanwhile, semantically, they express a wide range of ideas, depending on what they refer to. The common meanings carried by adjuncts can be related to place, time and process. However, there are also the meanings of respect and contingency. These meanings are then subdivided into some specific meanings (Park, 2016). Adjuncts may show position, direction and distance, in reference to spatial aspect. Position is associated with static condition, where it denotes certain point of location. Simply, it can be said to answer the question where. Secondly, direction refers to directional path either with or without loca- 
Vol. 2, No. 2, Juli 2018, 164

Available Online at https://ejournal.warmadewa.ac.id/index.php/kulturistik

DOI: dx.doi.org/10.22225/kulturistik.2.2.753

tional specification. Direction may refer to goal or source. They will be respectively elicited by the questions where to/from. Finally, the only adjunct representing place which can be measured is known as distance. It is elicited by question how far, and most of adjuncts indicating distance are realized by noun phrases.

Regarding to time aspect, there are time position, duration, frequency and time relation. Adjuncts of time may indicate a temporal scale, where it is considered static because it explains the time when an action takes place, or the time to which a state applies. This kind of adjunct conveys the meaning of position. Then, duration expresses the length of time. If the duration extends from the point of time forward to future, it is called forward span. This adjunct is characteristically realized by keyword 'until' or 'till'. In contrast, if the duration tends to indicate the stretch of time back from the speaker-hearer orientation point, it is known as backward span. The elicitation of duration as well as forward and backward span is usually achieved by the same question form how long. However, for future and past extent, alternative forms are generally available, such as till when and since when respectively. Time adjuncts sometimes carry the meaning of frequency which indicates how often the subject does something, so that it is recognized as frequency adjunct. Besides, they may also express a relationship between two time positions that are both being considered in an utterance. Time relationship adjuncts may denote temporal sequence and are also used for time position. Besides, they sometimes imply something of the concessive relation or compare one time with another.

Adjuncts referring to contingency may imply causative meaning, purpose, and concession. The term cause can be defined as what makes something happen. It can also be said as concerning with causation and motivation. Therefore, such adjuncts are able to respond the question why and they are marked by conjunction 'because' or prepositions representing causative meaning, such as 'because of' and 'from'. Purpose is also almost similar as cause since it contains the reason for which something is done or made. They are able to answer the question why as well, but they specifically respond what someone did something for. Thus, they are sometimes recognized by use of for or to-infinitive. Adjuncts are said to carry concessive meaning when they signal a contrast or concession in relation to the idea expressed in the main clause. They tend to be the opposite of adjuncts with causative meaning, however. In addition, adjuncts with concessive meaning are overtly introduced by 'in spite of' and 'despite' (Nurhasanah, 2017).

The meanings of manner, means, role, and instrument belong to process adjuncts. Manner reflects the attitude of the subject towards the verb in a sentence. It explains how the action is done and they are mostly recognized by adverb phrases and prepositional phrases. Then, adjuncts representing means tend to show the method in doing something. Similar as manner, adjuncts representing means can also be realized by adverb phrases. The difference between manner and means is that adverb phrases forming means adjuncts cannot be modified. Adjuncts implying instrument, on the other hand, expressing tools which is used to execute the action. Finally, adjuncts carrying agentive meanings appear in passive sentences. The question 'by whom/what is something done?' would elicit this kind of adjunct.

Finally, the last meaning which is possible to be carried by adjunct is respect. It can be said that respect adjuncts emphasize the idea of the sentence. Since most adjuncts are verb oriented, adjuncts of respect stress what actually the 
Vol. 2, No. 2, Juli 2018, 165

Available Online at https://ejournal.warmadewa.ac.id/index.php/kulturistik

DOI: dx.doi.org/10.22225/kulturistik.2.2.753

focus of the verb is. Therefore, the question what will elicit such adjunct.

In fact, adjuncts are very complex. It means that even though they are constructed by the same form, they may possess different meanings, or vice versa. The complexity of forms and meanings carried by adjuncts becomes a very essential point to discuss. People also need to be able to distinguish whether adverbials in a sentence is adjunct. Regarding to this fact, it seems interesting to identify the forms and meanings of adjuncts found in a novel in this scientific writing.

\section{METHOD}

The research approach applied in this study was qualitative approach because the data were shown descriptively by using words rather than showing numerical analysis. There are four steps which were conducted in writing this article: determining the data source, collecting the data, analyzing the data and presenting the results of analysis.

It is necessary to consider the sources on which to base and confirm the research and findings. In this article, the novel entitled Fifty Shades of Freed by Erika Leonard Mitchell (also known as E.L. James) was used as the data source. The data are sentences which contain adverbials functioning as adjunct. This novel was released in 2012 and it has 579 pages. This novel was selected because there are various kinds and forms of adjuncts to be analyzed. Moreover, the language used in this novel is formal English and this novel also became New York Times Bestseller.

After determining the data source, the next step was collecting the data. Collecting data means putting all the data together in one place in such a way so that they can be easily analyzed and interpreted. Library research was the method used to collect the data in this study. It was done through reading the novels first and marking the sentences which contain adverbials functioning as adjunct. The next step was note-taking where the sentences which contain adverbials functioning as adjunct were written down into a list, and then they were categorized based on their forms and meanings.

After all data were collected and classified, then they were analyzed one by one based on the theories applied. There were at least two examples for each category found. Some elaborations on each example were also given to analyze the data. The last step was presenting the results of analysis. Since the data analysis in this study was presented by using sentences, the presenting method applied was informal method.

\section{DISCUSSION}

The term 'adjunct' is actually very complex because it can be constructed by various forms. As what has been stated previously, the realizations of adjuncts are similar as adverbials. It means that adjuncts in the forms of phrases do exist. Even, certain clauses are also able to realize them. It is obvious that as one part of adverbial, adjuncts carry various meanings, depending on the context of the sentence. The meanings carried by adjuncts can be much more specific than what is commonly known. Generally speaking, adjunct which refers to place is not merely categorized as place adjunct, or even adjunct that implies when an event takes place actually carries more specific meaning than just time adjunct. As what has been mentioned previously, there are five semantic roles of adjuncts, namely: adjunct of space, adjunct of time, adjunct of process, adjunct of respect, and adjunct 
Vol. 2, No. 2, Juli 2018, 166

Available Online at https://ejournal.warmadewa.ac.id/index.php/kulturistik

DOI: dx.doi.org/10.22225/kulturistik.2.2.753

of contingency. These semantic roles are then categorized into several sub roles and they determine what meanings are actually carried by adjuncts.

\section{Adjuncts of Space}

Since adjuncts of space represent place or location, it can be said that such adjuncts are normally elicited by 'where?' question. It is known that space adjuncts can be distinguished into three sub roles which represent their specific meanings; they are position, direction, and distance. In adjuncts of space, position is associated with certain point of location and implies static condition. Simply, when adjuncts carry the meaning of position, they provide information about where an action takes place. Thus, questions like 'where is someone at?' and 'where does someone do something?' are able to elicit position adjuncts. Here are some examples of adjuncts carrying the meaning of position.

1) I stand by the French doors, watching the sun sink slowly over Seattle, casting bright orange and aquamarine shadows across the bay. (James, 2012: 13)

2) His iPod is in the speaker dock on the dresser. (James, 2012: 46)

The verb 'stand' in the first example implies static condition and it is followed by an adverbial of place by the French doors. This adverbial provides further information about the verb, and thus, it means that such adverbial is rather integrated within the structure of the sentence. Because it tends to be integrated, by the French doors is categorized into adjunct. In example (1), this adjunct is able to answer 'where does the subject stand?', so that it carries the meaning of position.

Adverbial in the speaker dock on the dresser in example (2) is absolutely integrated and obligatory. In other words, if such adverbial is removed, the sentence will be ungrammatical and meaningless. Therefore, it is also called obligatory adjunct. Additionally, because this adjunct has correlation to place, it belongs to space adjunct. The presence of adjunct in this second example as an adjunct can be elicited by question 'where is his iPod?' which needs to be answered by something showing location. As in the speaker dock on the dresser can possibly become the response of such question, it carries the meaning of position. Syntactically, adjuncts in the first two examples are formed by prepositional phrases for they are preceded by prepositions and then followed by noun phrases

If space position is associated with static condition, then direction indicates place with movement. To identify whether there is any movement, it can be seen from the verb of the sentence. Direction refers to directional path either with or without locational specification. There are two kinds of direction, namely: goal and source. The examples of adjuncts carrying the meaning of direction are presented as follows.

3) He leads me to the back of the cabin. (James, 2012: 19)

4) From his pocket, Christian produces his BlackBerry and gives it to Ted. (James, 2012: 539)

In example (3) above, the verb 'leads' indicates the existence of movement. This verb is then followed by an adjunct to the back of the cabin which represents a specific location. Thus, there is locational specification in this example. Since this adjunct shows movement and directional path, it can be said that adjunct in the first example carries the meaning of direction. In addition, adjunct to the back 
Vol. 2, No. 2, Juli 2018, 167

Available Online at https://ejournal.warmadewa.ac.id/index.php/kulturistik DOI: dx.doi.org/10.22225/kulturistik.2.2.753

of the cabin as the target location can be the answer of the question "where does he lead me?' according to the context of the sentence. Hence, more specifically, this adjunct has goal meaning.

On the other hand, adjunct from his pocket in example (4) is specifically referring to source. The movement aspect is represented by the verb 'produces'. This verb means 'to make something appear from somewhere'. Looking at the context of the sentence, the unit which undergoes a movement here is 'his BlackBerry'. Where this unit appears from can only be explained by adjunct from his pocket. Based on some examples above, it can be seen that adjuncts referring to direction mostly appear in prepositional phrases.

The only adjunct representing place which can be measured is known as distance. It is amount of space between two points or places. Adjunct carrying the meaning of distance can be elicited by question 'how far?' and thus, most of adjuncts indicating distance are realized by numbers with measuring units as in the following examples.

5) He dives beneath the sea and surfaces three feet away from me, then in a fluid, graceful crawl, swims away from the shore, away from me. (James, 2012: 10)

In this example, three feet away from me consists of a measuring unit 'feet', 'away' which provides detail about spatial aspect, and the number, in this case 'three', to describe the exact position of the subject. Additionally, these words are then followed by prepositional phrase 'from me' which indicates the point where the measurement is started. The appearance of three feet away from $m e$ in example (5) is considered obligatory since the verb 'surfaces' here needs an adverbial element indicating place to make the entire sentence grammatical. This adverbial is totally integrated within the sentence structure for it is able to be the response of the question 'where?' to indicate place. Apart from answering the 'when?' question, it can also be elicited by 'how far?' which is specifically showing distance.

\section{Adjuncts of Time}

In order to know whether adjuncts are referring to time, elicitation by using the question 'when?' can usually be done. Adjuncts of time also possess several specific meanings. These meanings include position, duration, frequency, and relationship. Adjuncts of time position may indicate a temporal scale, where it is considered static because it explains the point when an action takes place. In this case, adjuncts carrying the meaning of time position provide information about the time to which a state applies. The examples below are the realizations of adjuncts with time position meaning.

6) My body, ripe and ready, clenches deep inside. (James, 2012: 535)

7) Opening the door, I find Christian inside shaving, naked except for a towel wrapped around his waist. (James, 2012: 47)

The clause ripe and ready in example (6) above does not show its subject and verb. Thus, it can be said that there is omission (ellipsis) of those two elements and it makes the clause verbless. This clause consists of two adjectives which cannot stand alone, so they need the presence of linking verb in order to make its syntactic structure grammatical. Based on the context of the sentence, 
Vol. 2, No. 2, Juli 2018, 168

Available Online at https://ejournal.warmadewa.ac.id/index.php/kulturistik DOI: dx.doi.org/10.22225/kulturistik.2.2.753

adjunct ripe and ready seems to lose the subject 'it' which refers to 'my body' and the linking verb 'is'. Additionally, this adjunct represents when the action takes place, so it implies time position. To make this verbless clause sounds natural, conjunction 'when' which is also the feature of time can be added. In a sentence, adjunct is flexible. This means that it can be put in any position. Therefore, if the ellipsis in the second example is rewritten into its complete form, the entire sentence should be 'My body clenches (when) it is ripe and ready'. The addition of conjunction 'when' here also affirms that adjunct in this example refers to static time, which is the starting point of a sequence of events.

Meanwhile, adjunct opening the door implies the time meaning implicitly. It is necessary to rewrite adjuncts consisting of non-finite verb clause into their complete form to get the real meaning. Hence, opening the door in example (7) would be equal to 'when I open the door' since it explains when the action of finding Christian takes place. Because this adjunct contains 'the unseen' conjunction 'when', then it can be concluded that such adjunct conveys the meaning of time position.

Analogical with distance in adjunct of space, adjuncts carrying the meaning of duration can also be measured. They express the length of time from one point to another point of time. In this case, the point of time can be measured either from the time in the past up to the present time, or from the current time up to certain point in the future. If the duration extends from the point of time forward to future, it is called forward span. In contrast, if the duration tends to indicate the stretch of time back from the speaker-hearer orientation point, it is known as backward span. The examples of such adjuncts can be seen in the following discussion.

8) I'd like to stay until tomorrow. (James, 2012: 342)

9) "Christian, I've been yours since I said yes". (James, 2012: 22)

It can be seen that until tomorrow in example (8) refers to time duration as there is length of time which can be measured. The starting point of the measurement begins from the current time, when the speaker starts speaking. Meanwhile, the point of which the measurement considered to end is expressed by adjunct until tomorrow. This adjunct consists of preposition 'until', the feature of span referring to future, and 'tomorrow' which implies the exact point in the future. Additionally, until tomorrow is able to be the response of the question 'till when will the subject stay?' according to the context of the sentence.

The use of the conjunction 'since' in the finite clause since I said yes is a sign that it carries the meaning of time. This finite clause forming adjunct describes the stretch of time from certain point in the past up to the time in the present. Therefore, there must be interval between those points that can be measured, and it can be concluded that such adjunct carries the meaning of backward span. Moreover, the question like 'since when?' is able to elicit the adjunct in example (9).

Sometimes, adjuncts provide information about how often something happens, and they still have correlation to time aspect. Adjuncts which are able to be elicited by question 'how often?' are known to carry the meaning of frequency. Furthermore, they are presented as in the following examples.

10) We have sat here three, maybe four times total, and Christian usually reads a book. (James, 2012: 133) 
Vol. 2, No. 2, Juli 2018, 169

Available Online at https://ejournal.warmadewa.ac.id/index.php/kulturistik DOI: dx.doi.org/10.22225/kulturistik.2.2.753

11) He thrusts, once, twice, and again. (James, 2012: 135)

In example (10), there are actually two adjuncts representing time. The first one is adjunct three, maybe four times total which explains how many times the action represented by verb phrase 'have sat' occurs. It can be said that such adjunct contains an aspect of intensity or frequency. Secondly, adjunct usually in this sentence provides more details about how often the verb 'reads' happens, and thus, the question 'how often?' must be able to elicit it.

Meanwhile, adjunct once, twice, and again in example (11) expresses an action which is done continuously. Simply, this adjunct describes how many times the action of 'thrusts' is done by the subject based on the sentence. Hence, similar as in the previous example, adjunct once, twice, and again also refers to the aspect of intensity. So, adjuncts which carry the meaning of frequency mostly come in adverb phrases as in these two examples.

Adjuncts may express a relationship between two time positions that are both being considered in an utterance. Sometimes, they also imply something of the concessive relation or compare one time with another. This way, such adjuncts are said to carry the meaning of time relationship. Generally speaking, time relationship adjuncts denote temporal sequence and are also used for time position. Here are some examples of adjuncts conveying this meaning.

12) Mia is already jigging from foot to foot, itching to get onto the dance floor, and Ethan takes pity on her. (James, 2012: 299)

It can be seen that adjunct already above implies temporal sequence. The adverb 'already' describes the state before 'now'. Simply said, an event that consists of such adjunct may have been done previously, but it is still related to the current event (the 'now' point). The event which is meant in example (12) is 'jigging'. Since already has relation to another point of time, it is said to carry the meaning of time relationship.

\section{Adjuncts of Process}

Adverbials can be considered as adjuncts if they are able to be the response of some general questions, and 'how?' is one of them. In any occasion, the question 'how?' denotes the verb of the sentence. It can be said that it would elicit answer about how the action represented by the verb is done. Adjuncts which are associated with the verb of the sentence are known as adjuncts of process. There are several specific meanings carried by such adjuncts, namely: manner, means, instrument, and agentive meanings.

Adjuncts with the meaning of manner imply the way which is taken by the subject or the attitude of the subject toward the action represented by the verb itself. Generally, adjuncts representing manner can be elicited by 'how?' question. When they are about answering such question, they can usually be paraphrased 'in . . . manner' or 'in . . . way'. Here are some examples of adjuncts conveying the meaning of manner.

13) I snatch my hand out of his-in a cavalier, petulant, and childish manner. (James, 2012: 152)

14) He lifts me gently and lays me on the bed. (James, 2012: 262)

Semantically, adjunct in a cavalier, petulant, and childish manner in exam- 
ple (13) is considered as an adjunct of process since it shows how the action described by the verb 'snatch' is done. Simply, it is the attitude which is expressed by the subject toward this action. According to the context of the sentence, this adjunct may respond the question 'how does the subject snatch her hand out?', and thus, it carries the meaning of manner. Another feature that appears in this adjunct so that it can be considered to imply manner meaning is the presence of prepositional phrase 'in . . . manner'.

Constructed by adverb phrase, adjunct gently also belongs to process adjunct as it provides more details about how the verb 'lifts' is done. Briefly said, it shows the attitude of the subject toward this verb. Answering the question 'how does the subject lift someone?' adjunct gently can be paraphrased 'in a gentle manner'. It means that the feature of manner is also applied in example (14).

The terms manner and means seem to be similar as both of them describe the verb and explain the way taken to execute an action. However, means tends to reveal the method of conducting the action. Adjuncts carrying the meaning of means are also elicited by 'how?' question for they tell the action technically. Some examples below represent adjuncts with means meaning.

15) Putting his hands around my waist, he shifts me so I am sitting a little farther back on his lap. (James, 2012: 174)

16) But I'm not going to tell you via e-mail. (James, 2012: 415)

In example (15), the main verb which is described is 'shifts' that represents the action of the sentence. The clause putting his hands around my waist is made of the -ing participle which is similar as the seventh example and plays role as an adjunct. Hence, it is necessary to rewrite it into other form in order to find out what meaning it actually carries. The addition of preposition 'by' would make this adjunct clearer to understand, so it would be 'by putting his hands around my waist'. Referring to the context of the sentence, adjunct which has been rewritten as such is obviously presenting method. Therefore, the question 'how does he shift her?' can be answered by adjunct (by) putting his hands around my waist. It means this adjunct conveys the meaning of means.

Adjunct via e-mail in the second example also seems to describe process. The action which is emphasized here is represented by the verb 'tell'. This adjunct consists of two words: 'via' and 'e-mail'. The word 'via' itself can be defined as 'by means of a particular system'. Meanwhile, the word 'e-mail' is the representation of such system. The presence of this adjunct in example (16) may be elicited by 'how?' which is the general question for adjuncts referring to process. Because via e-mail in this occasion is interpreted as the means of telling something, then it is an adjunct carrying the meaning of means.

Sometimes, something is needed in order to conduct an action. The thing (or tool) which is used in executing certain action is called instrument. Some adjuncts are also known to carry the meaning of instrument as long as they can be the response of question 'how?' or more specifically by 'what is used for doing something?' question. Therefore, adjuncts conveying this meaning are usually featured by preposition 'with'. The sentences below consist of adjuncts carrying the meaning of instrument.

17) With one hand he pulls off the blindfold and grasps my chin, and I blink up into his scorching eyes. (James, 2012: 248)

18) She wipes my nose with a tissue as only a mother would. (James, 2012: 386) 
Vol. 2, No. 2, Juli 2018, 171

Available Online at https://ejournal.warmadewa.ac.id/index.php/kulturistik DOI: dx.doi.org/10.22225/kulturistik.2.2.753

It seems that adjunct with one hand in the example (17) explains the action which is represented by the verb phrase 'pulls off' and it is also able to be elicited by the 'how?' question. Instead of providing more description about manner or means, 'one hand' here refers to something which is used to conduct the action of 'pulling off the blindfold'. Thus, such adjunct would be able to be the response of the question 'what is used for pulling off the blindfold?' in this context. Simply said, this adjunct carries the meaning of instrument.

Similarly, adjunct with a tissue in example (18) is also describing process, as it explains the verb 'wipes'. Hence, it is able to respond the 'how?' question as in 'how does she wipe her nose?' It can be seen that adjunct with a tissue introduces its presence as a tool. More specifically, it can be elicited by a question like 'what does she use for wiping her nose?' according to the context. In addition, this adjunct consists of preposition 'with' and noun phrase 'a tissue' which plays role as the instrument.

The last meaning that is supposed to be carried by process adjuncts is agentive meaning. Adjuncts with such meaning appear in passive voice form, and thus, they can only be elicited by question 'by whom/what is something done?' Adjuncts carrying agentive meaning are mostly featured by preposition 'by' as the marker. Here are some examples of adjuncts with agentive meaning.

19) We are interrupted by an ashen-faced Sawyer; he stalks out of Christian's study and briskly crosses the great room. (James, 2012: 123)

20) I scowl at him, but I'm saved by Barney. (James, 2012: 127)

A clause in example (19) above is constructed in the passive form. The word 'we' plays role as the affected element, and verb phrase 'are interrupted' is the marker of passive voice since it consists of 'be' and followed by past participle. Meanwhile, 'an ashen-faced Sawyer' acts as the agentive element, who conducts the action represented by the verb. From here, it can be said that it is 'Sawyer' who 'interrupts us', and thus, adjunct by an ashen-faced Sawyer carries agentive meanings. Moreover, a question such 'by whom are you interrupted?' would be able to elicit the so-called agentive adjunct.

Focusing on the clause 'I'm saved by Barney' in example (20), it turns out that this clause also comes in passive construction. Here, the affected element is represented by 'I' and the passive marker is 'am saved'. On the other hand, 'Barney' plays its role as the agentive element in this clause for this element does the action of 'saving'. Hence, the stretch of words by Barney must be an adjunct with agentive meaning since it can be the response of 'by whom is she saved?' question.

\section{Adjuncts of Respect}

Adjuncts carrying the meaning of respect emphasize the idea of the sentence which is introduced by the verb. Different from adjuncts with process meaning, adjuncts of respect tend to expose what actually the focus of the verb is. Therefore, the question 'what?' is able to elicit such adjuncts. The examples of adjuncts carrying the meaning of respect can be seen as follows.

21) Will you talk to Gia about the rooms over the garage? (James, 2012: 184)

22) I'll help you dress. (James, 2012: 485)

Adjunct about the rooms over the garage provides more details about the 
Vol. 2, No. 2, Juli 2018, 172

Available Online at https://ejournal.warmadewa.ac.id/index.php/kulturistik DOI: dx.doi.org/10.22225/kulturistik.2.2.753

verb 'talk'. This adjunct becomes the focus of the sentence since it emphasizes the action represented by this verb. In fact, the verb 'talk' belongs to intransitive verb, and thus, the presence of adjunct about the rooms over the garage in example (21) can be omitted without making the entire sentence ungrammatical. In other words, it is considered optional. Additionally, such adjunct can be elicited by 'what?' question as in 'what will she talk about?' referring to the context of the sentence. Then, such adjunct is said to carry the meaning of respect.

Example (22) also has an optional element which is constructed by an infinitive clause dress. This clause is considered unnecessary so it only gives more details about the other element, in this case the main verb 'help'. Since it only describes the main verb, dress is categorized as an adverbial. In addition, such adverbial is integrated within the sentence structure because it provides an answer to general question 'what?' as in 'what kind of help?' based on the context of the sentence. Thus, dress can be classified as adjunct. This clause consists of the basic verb 'dress' only which is not affected by tense. It means that even though the tense in this sentence is changed, the clause 'dress' will remain the same. Such construction is known as bare infinitive.

\section{Adjuncts of Contingency}

Contingency is related to why or what makes something happen, what to do to make something occur, even what can be achieved from doing certain action. Adjuncts of contingency may carry several specific meanings. They are causative meaning, meaning of purpose, and concessive meaning. Adjuncts carrying the meaning of cause are able to respond the question 'what made the situation happen?' or simply 'why?' in some occasions. It concerns with causation and motivation from the subject of doing certain action. In addition adjuncts with causative meaning are marked by conjunction because, prepositions (such as because of and from). Further discussion related to adjuncts with causative meaning can be seen in the following examples.

23) "You're having doubts?" Kate asks, alarmed. (James, 2012: 12)

24) Unfortunately, he suffered a cardiac arrest during the operation because of blood loss. (James, 2012: 361)

There is an -ed participle forming adjunct in example (23). Adjunct alarmed above belongs to -ed clause because it is syntactically built from past participle and carries passive form. Even so, such clause is not affected by tense, like the other non-finite clauses. Looking at the context of the sentence in this example, adjunct alarmed describes more details about why the subject does the action 'ask'. Hence, it expresses causation and it can be rewritten as '. . . Kate asks because she was alarmed'.

Reflecting on the context of the sentence in example (24), it appears that because of blood loss provides further information about the cause of 'he suffered a cardiac arrest'. It can also be elicited by the general question 'why did he suffer a cardiac arrest during the operation?' which obviously reveals the causative meaning in it.

Purpose is the reason for which something is done or made. When adjuncts carry the meaning of purpose, they tend to answer the general question 'why?' or 'what did someone do something for?' Mostly, adjuncts with purpose meaning are marked by preposition for or to-infinitive. However, it turns out that they can 
Vol. 2, No. 2, Juli 2018, 173

Available Online at https://ejournal.warmadewa.ac.id/index.php/kulturistik DOI: dx.doi.org/10.22225/kulturistik.2.2.753

be realized in some other variations. Here are some examples of adjuncts carrying the meaning of purpose.

25) I am an adult female and went for a drink with my friend. (James, 2012: 229)

26) Taylor halts the Audi at the foot of the steps leading up to the plane and leaps out to open Christian's door. (James, 2012: 16)

Example (25) above seems to consist of two clauses, 'I am an adult female' and 'I went for a drink with my friend'. An adjunct appears in the second clause, and it provides further detail about the verb 'went'. What is explained by adjunct for a drink is the reason why the subject conducted the action represented by that verb. In other words, this adjunct exists as the response of question 'why did she go?' so that it also expresses something which was going to be achieved by the subject. Therefore, this adjunct conveys the meaning of purpose.

The adjunct to open Christian's door in example (26) is constructed by toinfinitive clause. Even though the construction of this adjunct is different from the previous one, the meaning they carry is the same. This adjunct also provides additional information related to the verb. It briefly explains why the subject (in this case Taylor) does the action (leaps out), and thus, the general question 'why?' is able to respond this adjunct. Since to open Christian's door represents something which is going to be achieved or to be done, it is said to carry the meaning of purpose as well.

Adjuncts are said to carry concessive meaning when they signal a contrast or concession in relation to the idea expressed in the main clause. Concessive meanings are overtly introduced by in spite of and despite. Further discussion about adjunct carrying the meaning of concession is presented in the following examples.

27) He looks thoughtful, despite his scowl. (James, 2012: 214)

28) In spite of the mess, the view is still stunning. (James, 2012: 518)

It can be seen that adjunct in example (27) carries concessive meaning. This is because adjunct despite his scowl shows inverted condition compared with its main clause 'he looks thoughtful'. The word 'scowl' and 'thoughtful' are actually contradictory. In addition, this adjunct is featured with preposition 'despite' as the marker of concession. Such adjunct can also act as an inoperative cause by changing the feature 'despite' into 'because of' and negating the main clause, so that the entire sentence would be 'he does not look thoughtful because of his scowl'.

Adjunct in spite of the mess in the last example also carries the same meaning as in the previous one. The presence of marker 'in spite of' signals that an adjunct has concessive meaning. Moreover, there are two things which are contradictory in this sentence, 'mess' and 'stunning'. A stunning view is closely related to beauty, cleanliness, and neatness. They are all opposite to 'mess' in this case. This adjunct can also appear as inoperative cause as in 'because of the mess, the view is not stunning anymore'.

\section{CONCLUSION}

Based on the results of analysis, there are two important points that can be concluded. These essential points are related to the forms and meanings of adjuncts found in a novel entitled Fifty Shades of Freed. First, adjuncts may appear 


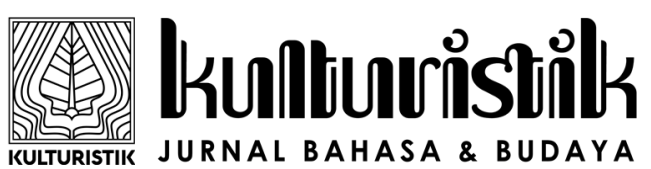

Vol. 2, No. 2, Juli 2018, 174

Available Online at https://ejournal.warmadewa.ac.id/index.php/kulturistik DOI: dx.doi.org/10.22225/kulturistik.2.2.753

in many forms, either phrases or clauses. Phrases forming adjuncts found in this novel are noun phrases, adverb phrases, and prepositional phrases. Meanwhile, clauses forming adjuncts which appear in this novel are finite verb clauses, nonfinite verb clauses (including to-infinitive, bare infinitive, -ing participles, and ed participles), and verbless clauses. Secondly, there are various meanings carried by adjuncts found in Fifty Shades of Freed. Adjuncts which denote space or place carry the meanings of position, direction (source and goal), and distance. Adjuncts referring to time carry the meanings of time position, duration (forward and backward span), frequency, and time relationship. Adjuncts showing process carry the meanings of manner, means, instrument, and agentive. Besides, there are also adjuncts which imply respect, cause, purpose, and concession found in this novel.

\section{REFERENCES}

James, E. L. (2012). Fifty Shades of Freed. New York: Vintage Books.

Nurhasanah. (2017). Circumstantial Adjuncts Used in the Tale: The Taming of the Shrew. Getsempena English Education Journal (GEEJ), 4(2), 118-126.

Park, H. (2016). Adverbials in L2 English of Korean Children. The Journal of Linguistic Science, 77, 81-107. https://doi.org/10.21296/j1s.2016.06.77.81

Petrlíková, J. (2013). Dependent Verbless Clause: Its Structure, Function and Use. Novitas-ROYAL (Research on Youth and Language), 7(1), 55-63.

Spasić, D., Babić-Antić, J., \& Spasić-Stojković, M. (2015). Adverb or Adverbial Phrases: Structure, Meaning, Function. Zbornik Radova Učiteljskog Fakulteta Prizren-Leposavić, 9, 177-191. https://doi.org/10.5937/ zrufpl1509177S

Torikai, S. (2013). Participle based "-edly" Adverbs in Legal Discourse. Language, Culture, and Communication: Journal of the College of Intercultural Communication, 5, 77-98. https://doi.org/10.14992/00005822 